\title{
Pharmacological effect of indolicidin-like peptides on vasoactive substances content in experimental periodontitis
}

\author{
Igor V. Kutepov $\mathbb{B}^{\text {, Y Yri D. Lyashev }}$ \\ Belgorod State National Research University, \\ 85 Pobedy St., Belgorod, 308015, Russia \\ Corresponding author: Yuri D. Lyashev (ylyashev@yandex.ru)
}

\begin{abstract}
Background: The anti-inflammatory effect of indolicidin-like peptides, which have a wide range of antimicrobial effects, has been already reported in several studies. The inflammation of the periodontium is accompanied by the endothelium injury and disorders of vasoactive substances formation. The investigation of the influence of potential periodontal protectors on the microcirculation and vasoactive substances production remains relevant. The aim of the study: To investigate the pharmacological effect of indolicidin-like peptides on the vasoconstrictor and vasodilator content in the animals with experimental periodontitis. Materials and methods: Experimental periodontitis was performed in accordance with the method proposed by A.I. Volozhin and S.I. Vinogradova. The pharmacological effect of indolicidin-like peptides N7 and N8 on the content of endothelin-1 in the homogenate of gum tissue and the concentration of nitric oxide decay substances in the plasma was studied. Rats with periodontitis were intraperitoneally injected with N7 and N8 peptides. The dose of peptides was $500 \mu \mathrm{g} / \mathrm{kg}$ in $0.2 \mathrm{ml}$ of normal saline once a day for 7 days. Results: The values of endothelin- 1 and nitric oxide decay products in the rats with periodontitis enhanced from the $7^{\text {th }}$ until the $21^{\text {st }}$ day of the experiment. Indolicidin-like peptides administration decreased the mean values of endothelin-1 and nitric oxide decay products in the rats with periodontitis at the $2^{\text {nd }}$ and the $3^{\text {rd }}$ weeks of the experiment. Conclusion: The data obtained indicate that indolicidin-like peptides N7 and N8 have protective effect on the vasoconstrictor-vasodilator balance in periodontitis and there was no significant difference in their influence.
\end{abstract}

Keywords: periodontitis; indolicidin-like peptides; endothelin; nitric oxide

For citation: Kutepov IV, Lyashev YD. Pharmacological effect of indolicidin-like peptides on vasoactive substances content in experimental periodontitis. Research Results in Biomedicine. 2021;7(1):67-71. Russian. DOI: 10.18413/2658-6533-20207-1-0-6 
Introduction. One of the directions of modern dentistry is the search for new effective drugs for treating inflammatory periodontal diseases. The leading role of periodontopatogenic bacteria in the provoking of the any forms of periodontitis and the lack of efficacy of currently using antibiotics make this problem especially important $[1,2,3]$.

That's why synthetic analogues of the natural peptide indolicidin, which have a wide range of antimicrobial effects, are of great interest to researchers $[4,5,6]$. Recently, we have shown the protective action of indolicidin-like peptides on morphological and biochemical changes in the periodontium in periodontal disease [7]. It's known that the inflammatory processes, including periodontitis, are accompanied with the disorders of vasoactive substances secretion [8].

The aim of the study is the evaluation of the pharmacological effect of indolicidinlike peptides on the content of endothelin-1 and nitric oxide decay products in the animals with experimental periodontitis.

Materials and methods. Eighty Vistar male rats were obtained from the branch "Stolbovaya" of the Federal State Budgetary Institution of Science "Scientific Center for Biomedical Technologies of the Federal Medical and Biological Agency". The naïve group consists of 8 animals. Experimental periodontitis was performed in accordance with the method proposed by A.I. Volozhin and S.I. Vinogradova [9]. The animals received the chloral hydrate intraperitoneally at a dose of $0.3 \mathrm{~g} / \mathrm{kg}$ b.w. and $2 \%$ novocaine solution locally. The silk thread was put in the form of eight on the lower incisors after the dissection of interdental papilla. Then the silk ligature was immersed in the periodontal groove and it was fixed with additional nodes for two weeks. The animals were sacrificed at the first, second and third weeks after by an overdose of anesthesia.

The concentration of endothelin- 1 in the gum tissue homogenate was measured by immune-enzyme assay using a set produced by Biomedica Medizinprodukte $\mathrm{GmbH} \mathrm{Co}$ $\mathrm{KG}$ (Austria) and it was expressed in $\mathrm{pmol} / \mathrm{ml}$. Preliminary, the gum tissue (100 $\mathrm{mg}$ ) was homogenized in the saline solution $(\mathrm{pH}=7.2)$ in the low temperature $\left(+2-+3^{\circ} \mathrm{C}\right)$ and then homogenate was centrifuged in 3000 rpm during 15 minutes.

Nitric oxide decay products content in the plasma was measured by a 546-nm spectrophotometer [10].

The rats with experimental periodontitis were divided into the following groups: control group (periodontitis and saline solution injections) -24 rats, the first experimental group (periodontitis and indolicidin N7 injections) - 24 rats, the second experimental group (periodontitis and indolicidin N8 injections) -24 rats.

The action of indolicidin-like peptides N7 (H - Ile - Leu - Pro - Trp - Lys - Lys Pro - Trp - Lys - Pro - Trp - Arg - Arg $\left.\mathrm{NH}_{2}\right)$ and $\mathrm{N} 8(\mathrm{H}-\mathrm{Ile}-\mathrm{Lys}-$ Pro - Trp - Lys - Trp - Pro - Trp -Lys - Pro - Trp - Arg Arg - $\mathrm{NH}_{2}$ ) (LLC "NPF" Verta"”, St. Petersburg, Russia)" on the periodontitis development was investigated. The rats in the control group were intraperitoneally injected with 0.2 $\mathrm{ml}$ of normal saline 7 days. The rats in experimental groups were injected under the same schedule with $0.2 \mathrm{ml}$ of the solution of $\mathrm{N} 7$ or $\mathrm{N} 8$ peptide in normal saline. The dose of indolicidin-like peptides was $500 \mu \mathrm{g} / \mathrm{kg}$ of body weight. The solution was prepared ex tempore. These doses were chosen on the basis of the literature data and preliminary experiments [7].

The study was carried out in accordance with the regulations for ensuring the human treatment of animals declared in the Helsinki Declaration of the World Medical Association on the Humane Attitude to Laboratory Animals (2000), European Community Directives (86/609 EC) and the Rules of Proper Laboratory Practice in the Russian Federation (Order No.199n of the Ministry of Public Health of the Russian Federation dated 01.04.2016). The approval of the Regional Ethics Committee (REC) (protocol No. 3 of 10.27.2015) was received.

Experimental results were statistically processed by methods of variation statistics. The significance of discrepancies was defined according to Student's t-criterion after the 
checking of normal distribution of the parameters. MS Excel and Statistica 10 software were used for statistical processing.

Results and discussion. Mean values of the endothelin-1 concentration in the gum homogenate and nitric oxide decay products in the plasma in the naïve, control and treated with indolicidin-like peptides $\mathrm{N} 7$ and $\mathrm{N} 8$ groups are shown in Table. The studied indices of the control group rats increased in comparison with those in the naïve animals during the entire observation. The arising in the content of nitric oxide decay products indicates to the reinforcement of nitric oxide turnover and a decrease in its concentration [8].

Table

\section{Pharmacological effect of indolicidin-like peptides on the endothelin-1 and the nitric oxide} decay products content in the rats with periodontitis. $(M \pm m), n=8$

\begin{tabular}{|c|c|c|c|}
\hline $\mathrm{Cr}_{\text {Group }}^{\text {Indices }}$ & Day of experiment & $\begin{array}{l}\text { Concentration of nitric } \\
\text { oxide decay products in } \\
\text { the plasma, mcmol/l }\end{array}$ & $\begin{array}{l}\text { Concentration of endo- } \\
\text { thelin-1 in the gum tis- } \\
\text { sue, pg/mg of protein }\end{array}$ \\
\hline \multicolumn{2}{|l|}{ Naïve group } & $14.1 \pm 0.4$ & $1.34 \pm 0.06$ \\
\hline \multirow[t]{3}{*}{ Control group } & 7 day & $19.7 \pm 0.7^{\mathrm{xxx}}$ & $2.13 \pm 0.05^{\mathrm{xxx}}$ \\
\hline & 14 day & $17.6 \pm 0.6^{\mathrm{xx}}$ & $2.56 \pm 0.04^{\mathrm{xxx}}$ \\
\hline & 21 day & $16.3 \pm 0.4^{\mathrm{xx}}$ & $1.76 \pm 0.04^{\mathrm{xxx}}$ \\
\hline \multirow{3}{*}{$\begin{array}{l}\text { Periodontitis }+ \text { indolicidin } \\
\text { N7 }\end{array}$} & 7 day & $18.9 \pm 0.6$ & $2.07 \pm 0.06$ \\
\hline & 14 day & $15.4 \pm 0.7 *$ & $1.90 \pm 0.05 * * *$ \\
\hline & 21 day & $14.0 \pm 0.4 * *$ & $1.39 \pm 0.03 * * *$ \\
\hline \multirow{3}{*}{$\begin{array}{l}\text { Periodontitis }+ \text { indolicidin } \\
\text { N8 }\end{array}$} & 7 day & $20.1 \pm 0.6$ & $2.12 \pm 0.06$ \\
\hline & 14 day & $15.6 \pm 0.6^{*}$ & $1.92 \pm 0.05 * * *$ \\
\hline & 21 day & $14.7 \pm 0.5^{*}$ & $1.41 \pm 0.05 * * *$ \\
\hline
\end{tabular}

Note: ${ }^{\mathrm{xx}}-\mathrm{p}<0.01,{ }^{\mathrm{xxx}}-\mathrm{p}<0.001$ in comparison with those in the naïve group; ${ }^{*}-\mathrm{p}<0.05,{ }^{*}-\mathrm{p}<0.01, * * *-\mathrm{p}<0.001$ in comparison with those in the control group.

The long-term treatment with indolicidin-like peptides N7 and N8 revealed a significant decrease in the endothelin-1 and nitric oxide decay products in rats with periodontitis at the $2^{\text {nd }}$ week of the experiment in comparison with those in the control group: nitric oxide stable metabolites concentration decreased by $12.5 \%$ and $11.4 \%(\mathrm{p}<0.05)$ and endothelin1 content - by $25.8 \%$ and $25.0 \%(p<0.001)$ after the injection of indolicidin analogues N7 and $\mathrm{N} 8$ respectively.

This dynamics continues at the $3^{\text {rd }}$ week: endothelin-1 and nitric oxide decay products turned out to be significantly less than in the control rats $(\mathrm{p}<0.05-0.01)$.

The results of our study confirm the data about disturbances in the endothelin and nitric oxide content in periodontitis [11, 12]. The pathogenesis of endothelium injury in the inflammation is complicated. The direct damaging effect of periodontal microbes on the vascular endothelium is mainly developed due to their adhesion and invasion into endothelial cells [13]. Endothelial damage leads to intra- vascular changes: platelet aggregation and the activation of coagulation [13]. It has been also established that ET-1 was involved in the regulation of proinflammatory interleukins, especially interleukin- $1 \mathrm{~b}$ expression in gingival tissues [11].

The microcirculation system provides mainly metabolic homeostasis in the organs and tissues. Recently it was declared that periodontitis is characterized by a significant decrease in capillary perfusion in the periodontium [8]. A critical decrease in microcirculation and vasomotor activity of blood vessels in patients with periodontitis is followed by disturbances in the microcirculation adaptation to local metabolic needs $[8,13]$.

The long-term administration of indolicidin-like peptides N7 and N8 was followed by a protective pharmacological effect on the content of vasoconstrictor and vasodilator. These data confirm that indolicidin-like peptides are able to correct microcirculation in the affected periodontium. In our opinion, the effect could be related to the action of the 
peptides on the vasoactive substances synthesis by the macrophages and platelets, including interleukins, arachidonic acid cascade metabolites, growth factors, etc. The stimulation of macrophage adhesion property indicating to their functional activation under the influence of synthetic indolicidins has been already established [14].

Comparative investigation of the pharmacological effect of indolicidin-like peptides on endothelin-1 and nitric oxide decay products content in periodontitis didn't reveal the significant difference. Further research is required for better understanding molecular mechanisms of vasoprotecting effect of synthetic indolicidins.

\section{Conclusion}

1. The increase in endothelin-1 content in gum tissue and nitric oxide decay concentration in plasma has been established in periodontitis.

2. The long-term administration of indolicidin-like peptides N7 and N8 had protective effect on the vasoactive substances content: endothelin-1 and nitric oxide.

3. There was no significant difference between the pharmacological effects of indolicidin analogues N7 and N8 on the vasoactive substances content in periodontitis.

\section{Financial support}

Supported by The Federal State Autonomic Educational Institution of Higher Education "Belgorod State National Research University”.

\section{Conflict of interests}

The authors have no conflict of interest to declare.

\section{References}

1. Cepov LM, Nikolaev AI, Petrova EV, et al. Pathogenetic substantiation of clinical use medicines in complex therapy of inflammatory periodontal diseases (a review of the literature). Parodontologiya. 2018;23(2):4-9. Russian. DOI: https://doi.org/10.25636/PMP.1.2018.2.1

2. Chepurova NI, Romanenko IG. Corrective effect of immunological drugs on oral microbiozinosis in patients with chronical apical periodontitis against the background of oral dysbiosis. Parodontologiya. 2019;24(2):173-177. Russian.
DOI: https://doi.org/10.33925/1683-3759-201924-2-173-177

3. Orekhova LYu, Loboda ES, Kosova EV, et al. Topical antibiotic therapy in periodontology. Parodontologiya. 2020;25(3):217-223. Russian. DOI: https://doi.org/10.33925/1683-3759-202025-3-217-223

4. Dong N, Li XR, Xu XY, et al. Characterization of bactericidal efficiency, cell selectivity, and the mechanism of short interspecific hybrid peptides. Amino Acids. 2018:50(3-4):453468. DOI: https://doi.org/10.1007/900726-0172531-1

5. Mirski T, Niemcewicz M, Bartoszcze $\mathrm{M}$, et al. Utilisation of peptides against microbial infections - a review. Annuals of Agriculcure and Environmental Medicine. 2017;25(2):205-210. DOI: https://doi.org/10.26444/aaem/74471

6. Dwivedi R, Aggarwal P, Bhavesh NS, et al. Design of therapeutically improved analogue of the antimicrobial peptide, indolicidin, using a glycosylation strategy. Amino Acids. 2019;51(1012):1443-1460.

DOI: https://doi.org/10.1007/s00726-019-02779-2

7. Kutepov IV, Lyashev YD. Pharmacological correction of periodontitis using synthetic analogues of indolicidin. Research Results in Pharmacology. 2019;5(3):21-35. DOI: https://doi.org/10.3897/rrpharmacology.5.38107

8. Leontyev VK., Faustov LA, GalenkoYaroshevskiy PA, et al. Chronic generalized periodontitis: clinical and experimental pharmacotherapy by metabolic correctors. Krasnodar: Prosveshenie-Yug Publishing; 2012. Russian.

9. Volozhin AI, Vinogradova SI. The modelling and treatment of the inflammation in the periodontium. Pathological physiology and experimental therapy. 1990;6:49-51. Russian.

10. Golikov PP, Nikolaeva NYu. The method of measurement of nitrite/nitrate (NOx) in serum. Biomeditsinskaya Khimiya. 2004;50(1):7985. Russian.

11.Isola G, Polizzi A, Alibrandi A, et al. Analysis of Endothelin-1 Concentrations in Individuals with Periodontitis. Scientific Reports. 2020;10(1):1652.

DOI: https://doi.org/10.1038/s41598-020-58585-4

12.Polak D, Sanui T, Nishimura F, et al. Diabetes as a risk factor for periodontal diseaseplausible mechanisms. Periodontology 2000. 2020;83(1):46-58. https://doi.org/10.1111/prd.12298

13. Silva NLC, Motta NAV, Soares MA, et al. Periodontal status, vascular reactivity, and platelet aggregation changes in rats submitted to hypercholesterolemic diet and periodontitis. Jour- 
nal of Periodontal Research. 2020;55(3):453-463.

DOI: https://doi.org/10.1111/jre.12730

14. Kutepov IV, Lyashev YuD, Artushkova $\mathrm{EB}$, et al. The influence of indolicidin analogues on the content of the connective tissue matrix of periodontium in the acute periodontitis. Parodontologiya. 2019;24(1):34-38. Russian. DOI: https://doi.org/10.30906/0869-2092-2019-82-12$36-40$

Received 12 November 2020

Revised 10 January 2021

Accepted 15 January 2021

\section{Information about the authors}

Igor V. Kutepov, Post-graduate Student in Scientific Specialty 14.03.06 - Pharmacology, Clinical Pharmacology, Belgorod State National Research University, Belgorod, Russia, E-mail: kutepoviv@ yandex.ru, ORCID: 0000-0002-2816-2787.

Yuri D. Lyashev, Doct. Sci. (Medicine), Professor at the Department of Pharmacology and Clinical Pharmacology, Belgorod State National Research University, Belgorod, Russia, E-mail: ylyashev@yandex.ru, ORCID: 0000-0003-0536923X. 